\title{
PENGARUH MACAM EKSTRAK BAHAN ORGANIK DAN ZPT TERHADAP PERTUMBUHAN PLANLET ANGGREK HASIL PERSILANGAN PADA MEDIA KULTUR
}

\section{EFFECT ADDITION OF ORGANIK MATTER EXTRACT AND PGR INTO CULTURE MEDIA TO THE GROWTH OF CROSS BREED ORCHID EXPLANTS}

\author{
Sri Hartati \\ Fakultas Pertanian UNS
}

\begin{abstract}
ABSTRAK
Penelitian bertujuan untuk mengetahui pengaruh macam komposisi dengan penambahan bahan organik (ekstrak kedelai, jagung dan minyak ikan) dan konsentrasi ZPT pada media kultur terhadap pertumbuhan planlet anggrek hasil persilangan. Penelitian dilaksanakan di Laboratorium Fisiologi dan Bioteknologi Tanaman Fakultas Pertanian UNS mulai bulan April sampai dengan Oktober 2009 Penelitian ini dilaksanakan dengan menggunakan Rancangan Acak Lengkap dengan 2 faktor perlakuan, yaitu : Faktor I adalah media bahan organik, terdiri dari 3 taraf : ekstrak kedelai, ekstrak jagung, dan minyak ikan. Faktor II adalah konsentrasi atonik, terdiri dari 3 taraf : $0 \mathrm{cc} / 1 \mathrm{tr}, 0,5 \mathrm{cc} / \mathrm{ltr}$, dan $1 \mathrm{cc} / \mathrm{ltr}$. Masingmasing kombinasi perlakuan diulang 4 kali.

Hasil penelitian menunjukkan bahwa anggrek hasil persilangan qPhalaeonopsis pinlong cinderela $><\widehat{\jmath}$ Phalaeonopsis joanekileup June", perlakuan bahan organic jagung memberikan pengaruh nyata terhadap saat kemunculan akar (21,83 HST) dan jumlah akar (1,92).Perlakuan bahan organic minyak ikan memberikan hasil yang berbeda nyata terhadap panjang akar $(2,82 \mathrm{~cm})$ dan jumlah akar $(1,92)$, serta memberikan hasil terbaik terhadap panjang daun. Sedangkan untuk perlakuan ZPT Atonik dapat menambah jumlah daun dan jumlah akar.
\end{abstract}

\section{ABSTRACT}

This research aimed to study the effect of kinds of culture media composition added with organic matter (soya bean extract, corn extract and fish emulsion) and PGR concentration to the growth of each cross breed orchid explants. Research was conducted in Plant Physiology and Biotechnology Laboratory, Agriculture Faculty, Sebelas Maret University of Surakarta from March 2009 until the end. This research was done in Randomized Completely Design with two factors of treatment and four replications. The first factor was media and organic matter, consist of 3 levels: soya bean extract, corn extract and fish emulsion. The second factor was atonik concentration, consist of 3 levels: $0 \mathrm{cc} / \mathrm{l}, 0.5 \mathrm{cc} / \mathrm{l}$ and $1 \mathrm{cc} / \mathrm{l}$.

The research concluded that for the explants of crossing (Phalaeonopsis pinlong cinderela $q><$ Phalaeonopsis joanekileup June" \$) two treatment of corn extract affected significantly to the root emergence time (21.33) and member of root (1,92 day after planting) The treatment of fish emulsion affected significantly to the root length $(2,82 \mathrm{~cm})$, number of root $(1,92)$ and produced the longest leaf. The treatment of Atonik increased the number of leaf and root.

\section{PENDAHULUAN}

Permintaan pasar anggrek $\begin{array}{r}\text { cenderung } \\ \text { tahunnya, namun }\end{array}$
meningkat setiap produksi anggrek di Indonesia
perkembangan produk
masih relatif lambat (Widiastoety, 2001).
Anggrek yang diminati pasar adalah anggrek
dengan kapasitas produksi bunga tinggi dengan
bentuk dan warna yang menarik, mahkota bunga
kompak, tekstur tebal, tahan lama sebagai bunga
potong, jumlah kuntum bunga banyak, kuntum
bunga tidak gugur dini akibat kelainan genetis,

serta tahan terhadap hama dan penyakit (Sutiyoso dan Sarwono, 2002).

Persilangan yang berhasil akan menghasilkan buah. Biji-biji dalam buah anggrek dikecambahkan dalam media tanam berupa agar-agar yang telah diperkaya dengan unsur-unsur hara untuk membantu perkecambahan. Hal ini karena biji anggrek ukurannya sangat kecil dan tidak memiliki endosperm. Pada medium kultur anggrek seringkali ditambahkan bahan alami. Bahanbahan alami atau zat nabati pada umumnya merupakan sumber gula, vitamin, zat pengatur 
tumbuh dan asam amino. Keberhasilan penggunaan metode kultur jaringan sangat tergantung pada jenis media. Media kultur tidak hanya mengandung unsur hara makro dan mikro, tetapi juga karbohidrat sebagai sumber karbon atau bahan organic lainnya. (Widiastoety dan Purbadi, 2003). Media tumbuh yang sering digunakan dalam budidaya anggrek secara in vitro adalah Vacin and Went. Sedangkan zat pengatur tumbuh yang sering digunakan adalah jenis auksin. Penggunaan media dan zat pengatur tumbuh yang tepat diharapkan pertumbuhan in vitro anggrek menjadi lebih baik.

\section{METODE PENELITIAN}

Penelitian dilaksanakan di Laboratorium Fisiologi dan Bioteknologi Tanaman Fakultas Pertanian Universitas Sebelas Maret Surakarta mulai bulan April sampai Oktober 2009. Bahan yang digunakan adalah eksplan anggrek hasil persilangan, yaitu $\mathrm{A}_{2} \mathrm{~W}$ ( Phalaeonopsis pinlong cinderela $><$ ते Phalaeonopsis joanekileup "June") media Vacint and Went (VW), ekstrak kedelai 100 gr/liter, ekstrak jagung 100 gr/liter, minyak ikan 4 cc/liter, aquades, sabun cuci, alkohol, dan ZPT Atonik (0,5 cc/l dan $1 \mathrm{cc} / \mathrm{l})$. Alat-alat yang digunakan dalam penelitian adalah tabung reaksi, rak tabung reaksi, laminar air flow cabinet (LAFC), autoklaf, magnetic stirrer atau hot plate stirrer, $\mathrm{pH}$ meter, petridish, gelas ukur, pipet, kapas, tissue, kertas label, peralatan diseksi (pinset besar dan kecil, pisau scalpel dan pemes, gunting eksplan), timbangan analitik dan batang pendorong.

Penelitian ini dilaksanakan dengan menggunakan Rancangan Acak Lengkap (RAL) dengan 2 faktor perlakuan, faktor I adalah bahan organik, terdiri atas ; ekstrak kedelai, ekstrak jagung, minyak ikan. Faktor II adalah konsentrasi ZPT atonik, terdiri atas ; $0 \mathrm{cc} / 1,0,5$ cc/1, dan $1 \mathrm{cc} / 1$. Didapat 9 kombinasi perlakuan, dengan masing-masing kombinasi perlakuan diulang sebanyak 4 kali. Pelaksanaan Penelitian meliputi sterilisasi alat, pembuatan larutan stok, pembuatan media, penanaman eksplan, serta pemeliharaan. Sedangkan untuk variabel pengamatan meliputi saat kemunculan akar pertama plantlet, panjang daun, panjang akar, jumlah daun, dan jumlah akar. Data yang diperoleh selanjutnya dianalisis ragam dengan uji $\mathrm{F}$ pada taraf $5 \%$. Jika perlakuan berpengaruh nyata maka dilanjutkan dengan Uji Jarak Berganda Duncan's (DMRT) pada taraf $5 \%$.

\section{HASIL DAN PEMBAHASAN}

\section{Saat Muncul Akar}

Akar merupakan organ vegetatif utama yang memasok air, mineral dan bahan-bahan yang penting untuk pertumbuhan dan perkembangan tanaman (Gardner et al., 1991). Saat munculnya akar menjadi faktor yang penting dalam pertumbuhan tanaman karena tanaman akan lebih mudah menyerap unsur-unsur yang terdapat dalam media kultur.

Hasil Uji Jarak Berganda Duncan 5\% untuk rerata saat kemunculan akar dapat dilihat pada tabel dibawah ini.

Tabel 1. Pengaruh tunggal perlakuan bahan organic dan konsentrasi ZPT terhadap Saat muncul akar (HST)

\begin{tabular}{lc}
\hline Perlakuan & Purata \\
\hline Bahan Organik & \\
Kedelai & $35,75 \mathrm{a}$ \\
Jagung & $21,83 \mathrm{~b}$ \\
Minyak Ikan & $26,25 \mathrm{ab}$
\end{tabular}

Konsentrasi ZPT Atonik

$\begin{array}{ll}\text { Ao }: 0 \mathrm{cc} / 1 & 22,67 \mathrm{a} \\ \text { A1 }: 0,5 \mathrm{cc} / 1 & 32,16 \mathrm{a} \\ \text { A2 }: 1 \mathrm{cc} / 1 & 29,00 \mathrm{a}\end{array}$

Keterangan :

Angka yang diikuti huruf sama pada masingmasing perlakuan menunjukkan tidak berberda nyata pada DMRT $5 \%$

Dari hasil Analisis ragam didapat bahwa pemberian bahan organik (ekstrak kedelai, ekstrak jagung dan minyak ikan) memberikan pengaruh berbeda nyata terhadap saat kemunculan akar. Sedangkan untuk ZPT memberikan pengaruh tidak berbeda nyata terhadap saat kemunculan akar. Pembentukan akar memerlukan energi yang digunakan untuk pembelahan sel-sel penyusun akar. Bahan organik ekstrak jagung memberi pengaruh saat muncul akar yang tercepat (21,83 HST). Hal ini diduga karena jagung mengandung auksin alami yang dapat merangsang munculnya akar. Auksin alami banyak terdapat didalam cairan biji jagung muda yang masih berwarna kuning muda keputihan dan isinya encer-lunak atau disebut juga stadium masak susu (Anonim, 2005).

Perlakuan pemberian Zat Pengatur Tumbuh (ZPT), semua konsentrasi memberikan pengaruh tidak berbeda nyata terhadap saat kemunculan akar. Perlakuan ZPT 0 cc/l memberikan pengaruh kemunculan akar tercepat (22,67 HST). Hal ini diduga bahwa auksin alami yang didapat dari ekstrak jagung sudah memberikan hasil yang optimal terhadap 
munculnya akar. Setiap tanaman mempunyai kemampuan yang berbeda-beda dalam menyerap ZPT untuk merangsang pertumbuhannya.

\section{Panjang Daun}

Hasil Uji Jarak Berganda Duncan 5\% bahwa perlakuan yang diberikan, baik pemberian bahan organik maupun zat pengatur tumbuh memberikan hasil tidak berbeda nyata terhadap panjang daun. Kombinasi perlakuan bahan organik minyak ikan dan ZPT atonik $0 \mathrm{cc} / 1$ memberikan pengaruh terhadap panjang daun yang paling baik.yaitu $1,48 \mathrm{~cm}$. Hal ini diduga karena minyak ikan banyak mengandung protein yang merupakan senyawa yang membantu dalam penyusunan daun. Sedangkan untuk perlakuan ZPT atonik $0 \mathrm{cc} / 1$ memberikan pengaruh yang paling baik karena memang auksin lebih aktif bekerja dalam pembentukan daun. Analisis ragam menunjukkan bahwa terdapat interaksi antara kedua faktor yaitu bahan organik dan ZPT atonik. Penambahan bahan organik akan membantu dalam pertumbuhan daun. Bahan organik banyak mengandung unsur-unsur yang diperlukan dalam pertumbuhan daun, sehingga pertambahan panjang daun akan semakin cepat. Sedangkan auksin lebih berperan dalam pembentukan daun dari pada pertumbuhanya. Penambahan auksin justru akan menghambat pertumbuhan daun karena auksin justru akan lebih aktif membentuk daun.

\section{Panjang Akar}

Panjang akar merupakan hasil perpanjangan sel-sel di belakang meristem ujung (Dewi, 2007). Pengukuran panjang akar dilakukan dengan mengukur akar terpanjang pada planlet. Selain untuk menyerap unsur hara, akar berfungsi sebagai penguat berdirinya tanaman. Semakin panjang akar diharapkan bidang penyerapan unsur hara semakin luas, sehingga distribusi nutrisi dari media tanam ke tanaman dapat berjalan dengan lancar. Hal ini juga dapat membantu dalam proses aklimatisasi, yaitu menunjukkan planlet dalam keadaan sehat sehingga memungkinkan tingginya prosentase keberhasilan aklimatisasi.

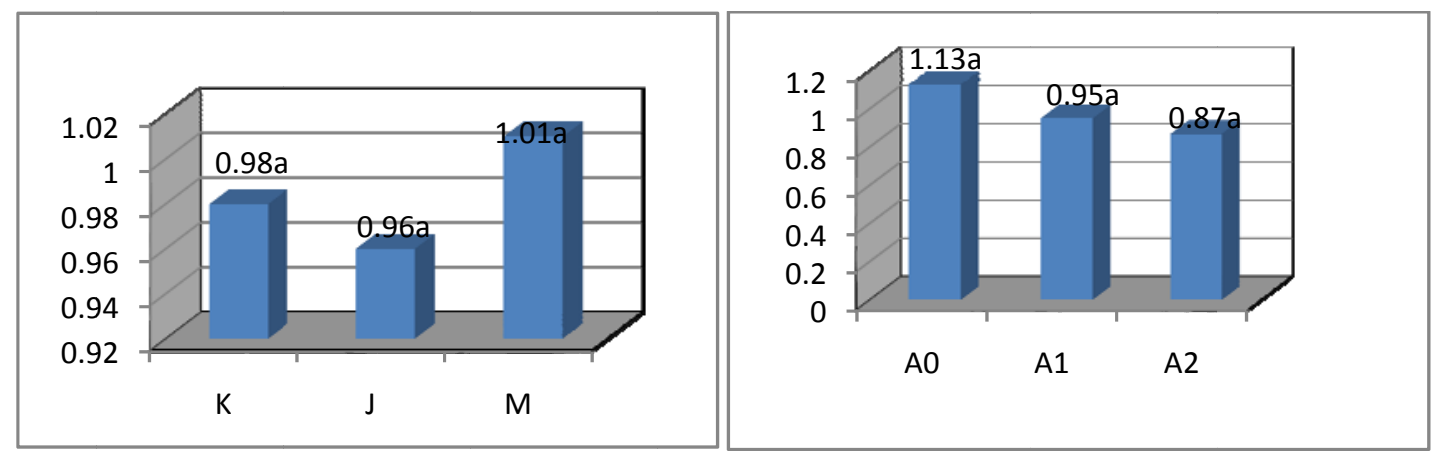

Gambar 1. Histogram rerata pengaruh bahan organik dan ZPT terhadap panjang daun

Tabel 2. Pengaruh tunggal perlakuan bahan organic dan konsentrasi ZPT terhadap Panjang akar $(\mathrm{cm})$

\begin{tabular}{lc}
\hline Perlakuan & Purata \\
\hline Bahan Organik & \\
Kedelai & $1,49 \mathrm{~b}$ \\
Jagung & $2,54 \mathrm{a}$ \\
Minyak Ikan & $2,82 \mathrm{a}$ \\
Konsentrasi ZPT Atonik & \\
Ao $: 0 \mathrm{cc} / 1$ & $2,75 \mathrm{a}$ \\
$\mathrm{A} 1: 0,5 \mathrm{cc} / 1$ & $2,03 \mathrm{~b}$ \\
$\mathrm{~A} 2: 1 \mathrm{cc} / 1$ & $2,07 \mathrm{~b}$ \\
\hline
\end{tabular}

Keterangan :

Angka yang diikuti huruf yang sama pada masing-masing perlakuan menunjukkan tidak berpengaruh nyata pada DMRT $5 \%$
Berdasarkan hasil analisis ragam diketahui bahwa pemberian bahan organik dan zat pengatur tumbuh berpengaruh nyata terhadap variabel panjang akar. Sedangkan interaksi antara kedua perlakuan memberikan pengaruh tidak berbeda nyata terhadap panjang akar.

Seperti yang dikatakan oleh Maynerd et al. (1991) dalam Gati et al. (1993) yang menyatakan bahwa kelebihan auksin dapat menghambat elongasi akar. Menurut Pelosi et al. (1995) cit. Vuylseteker et al. (1998) cit. Rostiana dan Seswita (2007) pemberian auksin dapat membentuk akar lebih banyak, tetapi akan menghambat proses pemanjangan akar lateral. Hal ini sesuai dengan pendapat Salisbury dan Ross (1995) bahwa konsentrasi zat pengatur tumbuh yang terlalu tinggi untuk suatu jenis 
tanaman tertentu akan mendorong sintesis etilen yang kemudian menghambat pemanjangan akar.

\section{Jumlah Daun}

Jumlah daun merupakan salah satu indikator pertumbuhan tanaman dan dapat digunakan sebagai data penunjang untuk menjelaskan proses pertumbuhan yang terjadi (Sitompul dan Guritno, 1995). Berdasarkan hasil analisis didapat bahwa bahan organik dan pemberian zat pengatur tumbuh atonik serta interaksi kedua perlakuan tidak memberikan pengaruh yang nyata terhadap jumlah daun yang terbentuk. Dari beberapa bahan organik yang ditambahkan, ekstrak kedelai berpengaruh paling baik terhadap jumlah daun yang terbentuk (1 helai daun). Untuk perlakuan pemberian zat pengatur tumbuh, konsentrasi atonik $0,5 \mathrm{cc} / 1$ dan
$1 \mathrm{cc} / 1$ memberikan pertambahan jumlah daun paling baik yaitu sebesar 0,92 helai daun. Sedangkan kombinasi perlakuan paling baik terhadap jumlah daun pada kombinasi perlakuan bahan organik ekstrak kedelai dan ZPT atonik 1 $\mathrm{cc} / 1$ yaitu sebesar 1,25 helai daun.

\section{Jumlah akar}

Pembentukan akar pada plantlet merupakan salah satu hal yang penting karena dapat meningkatkan pertumbuhan selama proses perbanyakan secara in vitro. Hal ini sering didekati melalui luas permukaan akar dan jumlah unsur hara yang tersedia dalam media, karena kebutuhan tanaman akan unsur hara yang tersedia dalam media perakaran akan saling mengisi (Sitompul dan Guritno,1995).

Tabel 3. Purata jumlah daun pada berbagai bahan organik bahan organik dan ZPT.

\begin{tabular}{ccccc}
\hline \multirow{2}{*}{$\begin{array}{c}\text { Bahan } \\
\text { Organik }\end{array}$} & A0 & A1 & A2 & \\
\cline { 2 - 4 } & 0,75 & 1,00 & 1,25 & $1,00 \mathrm{a}$ \\
$\mathrm{K}$ & 0,50 & 1,00 & 0,50 & $0,75 \mathrm{a}$ \\
$\mathrm{J}$ & 1,00 & 0,75 & 1,00 & $0,83 \mathrm{a}$ \\
$\mathrm{M}$ & $0,75 \mathrm{a}$ & $0,92 \mathrm{a}$ & $0,92 \mathrm{a}$ & $(-)$ \\
\hline
\end{tabular}

Keterangan : Angka yang diikuti huruf yang sama pada masing-masing perlakuan menunjukkan tidak berpengaruh nyata pada DMRT $5 \%$

Tabel 4. Purata Jumlah akar pada berbagai bahan organik bahan organik dan ZPT.

\begin{tabular}{ccccc}
\multirow{2}{*}{$\begin{array}{c}\text { Bahan } \\
\text { Organik }\end{array}$} & \multicolumn{4}{c}{ ZPT Atonik } \\
\cline { 2 - 4 } & A0 & A1 & A2 & \\
\hline K & 1,75 & 1,00 & 1,50 & $1,42 \mathrm{~b}$ \\
$\mathrm{~J}$ & 1,50 & 2,25 & 2,00 & $1,92 \mathrm{a}$ \\
$\mathrm{M}$ & 1,50 & 2,75 & 1,50 & $1,92 \mathrm{a}$ \\
Rerata & $1,58 \mathrm{a}$ & $2,00 \mathrm{a}$ & $1,67 \mathrm{a}$ & $(-)$ \\
\hline
\end{tabular}

Keterangan : Angka yang diikuti huruf yang sama pada masing-masing perlakuan menunjukkan tidak berpengaruh nyata pada DMRT $5 \%$

Hasil analisis ragam dapat ketahui bahwa bahan organik memberikan pengaruh berbeda nyata terhadap jumlah akar yang terbentuk. Sedangkan untuk perlakuan ZPT dan interaksi kedua faktor memberikan hasil yang tidak berbeda nyata terhadap jumlah akar yang terbentuk..Perlakuan bahan organik ekstrak jagung dan minyak ikan menghasilkan jumlah akar yang paling banyak dari ketiga perlakuan sebesar 1,92. Kedua bahan organik ini banyak mengandung senyawa yang dibutuhkan dalam pertumbuhan tanaman maupun pembentukan akar. Seperti yang dungkapkan oleh Admin (2008) bahwa, minyak ikan mengandung beberapa jenis asam lemak (asam lemak tidak jenuh seperti palmitat, asam lemak tidak jenuh tunggal seperti oleat dan asam lemak tidak jenuh ganda seperti linoleat, linolenat, asam 
eikosapentanoat (EPA), dan asam dokosaheksanoat (DHA). Minyak ikan juga mengandung vitamin $A$ dan $D$ jenis vitamin yang larut dalam lemak- dalam jumlah tinggi. Selain itu, minyak ikan juga mengandung protein, vitamin, mineral dan asam lemak omega-3. Begitu halnya dengan jagung banyak mengandung karbohidrat serta auksin alami yang dapat merangsang terbentuknya akar. Akar tanaman tumbuh dan berkembang mengikuti respon ketersediaan unsur hara dan status zat pengatur tumbuh yang ditambahkan, khususnya auksin. Akar tanaman akan berkembang dengan pesat apabila kebutuhan unsur hara yang dibutuhkan oleh tanaman terbatas. (Anonim ,2007 cit. Angestiwi, 2007).

\section{KESIMPULAN}

1. Pemberian ekstrak bahan organic jagung mempercepat saat muncul akar (21,83 HST) dan menambah jumlah akar terbanyak $(1,92)$,pemberian ekstrak kedelai berpengaruh terhadap jumlah daun, pemberian minyak ikan berpengaruh terhadap panjang akar terpanjang $(2,82 \mathrm{~cm})$ dan jumlah akar terbanyak

2. Pemberian ZPT Atonik dapat menambah jumlah daun dan jumlah akar.

\section{DAFTAR PUSTAKA}

Admin. 2008. Kandungan Gizi Minyak Ikan. http://www.sulastowo.com/2008/04/27/kan dungan-gizi-minyak-ikan/. Diakses pada Tanggal 28 Maret 2009.

Angestiwi, D. 2007. Pengaruh konsentrasi pupuk daun dan macam media terhadap pertumbuhan bibit tanaman Anthurium (Anthurium jemanii). Skripsi S1 Fakultas Pertanian UNS. Surakarta.

Anonim. 2005. Hormon Organik: http://www.iel.ipb.ac.id/sac/hibah/2003/sf tumbuhan/zpt.html. Diakses tanggal 17 Maret 2009.

Anonim. 2007. Budidaya Tanaman Anggrek. http://www.anggrek.org/?p=9\&page $=1 \& c p$ =9. Diakses tanggal 17 Maret 2009 .

Anonim. 2008. kultur jaringan. http://id.wikipedia.org/wiki/kulturjaringan. Diakses tanggal 17 Maret 2009.

Anonim.,2009 a. Vanda Tricolor. http://www.iptek.net.id/ind/pd anggrek/in dex.php?mnu=2\&id=170. Diakses tanggal 17 Maret 2009.
Anonim. $2009 \quad$ b. $\quad$ Kedelai. http://id.wikipedia.org/wiki/Kedelai. Diakses tanggal 17 Maret 2009

Dewi, I. R. 2007. Rhizobacteria Pendukung Pertumbuhan Tanaman. Makalah. Fakultas Pertanian Universitas Padjadjaran. Jatinangor.

Gardner, F. P., R. B. Pearce, dan R. L. Mitchell. 1991. Fisiologi Tanaman Budidaya. Universitas Indonesia. Jakarta.

Gati, E., I. Mariska dan D. Seswita, 1993. Daya regenerasi tanaman piretrum setelah penyimpanan melalui kultur jaringan. Prosiding Hasil Penelitian dalam Rangka Pemanfaatan Pestisida Nabati. Bogor: 126 -131 .

Kusumo. S, 1984. Zat Pengatur Tumbuh Tanaman. C.V.Yasaguna. 75 p. Pengkajian BPTP Jawa Timur. Belum dipublikasi.

Rostiana, O dan D. Seswita. 2007. Pengaruh Indole Butyric Acid dan Naphtaleine Acetic Acid terhadap induksi perakaran tunas Piretrum (Chrysanthemum cinerariifolium (Trevir.)Vis.) Klon Prau 6 secara in vitro. Bull. Littro 18 (1) : $39-48$.

Salisbury, F.B. and C.W. Ross. 1992. Plant Physiology. 4th Edition. California wardsworth Publ. Co.

Sitompul, S.M. dan B. Guritno. 1995. Analisis Pertumbuhan Tanaman. UGM Press. Yogyakarta.

Syamsir, Elvira. 2008. Pembuatan Susu Jagung. http://id.shvoong.com/exactsciences/1804557-pembuatan-susujagung/. Diakses tanggal 13 Maret 2009.

Sutiyoso, Y dan Sarwono. 2002. Merawat Anggrek. PT Penebar Swadaya. Jakarta.

Widiastoety, D. 2001. Perbaikan genetik dan perbanyakan bibit secara in vitro dalam mendukung pengembangan anggrek di Indonesia. Jurnal Litbang Pertanian. 2 (4) :138-143.

Widiastoety, D dan Purbadi. 2003. Pengaruh bubur ubi kayu dan ubi jalar terhadap pertumbuhan plantlet anggrek Dendrobium. J. Hort. 13 (1) : 1-5.

Widiastoety, D. dan S. Kartikaningrum. 2003. Pemanfaatan ekstrak ragi dalam kultur in vitro plantlet media anggrek. J. Hort. 13 (2) : 83-86.

Winarsih, s dan Priyono. 2000. Penagruh zat pengatur tumbuh terhadap pembentukan dan pengakaran tunas mikro pada asparagus secara in vitro. J. Hortikultura. 10(1) : 11-17. 